\title{
Issues in Clinical Learning Environment among Undergraduate Nursing Students in Khyber Pakhtunkhwa, Pakistan
}

\author{
Asghar Khan ${ }^{1}$, Hamida Begum ${ }^{2}$ \\ ${ }^{1}$ Principal, Pak-Swiss Nursing College Swat, Khyber Pakhtunkhwa, Pakistan \\ ${ }^{2}$ Nursing Instructor, School of Nursing Bannu, Khyber Pakhtunkhwa, Pakistan
}

\begin{abstract}
A B S TRACT
Background: Nursing students apply theoretical and evidence-based knowledge on real patients in clinical placements, thus poor clinical education may affect their performance along with patient care. The perceptions of nursing internees may serve as a solid evidence of issues in clinical learning. The objective of this study was to identify issues regarding clinical learning among undergraduate nursing students.

Material and Methods: A descriptive cross-sectional design was employed to collect data from a sample of 72 graduated Nursing Internees from Nursing Colleges in the Khyber Pakhtunkhwa (KPK) province of Pakistan. This study was conducted from April 2019 to August 2019. A Questionnaire in the form of Likert scale was developed for data collection regarding past experiences of their undergraduate studies. SPSS 22 was used for analysis. Chi-squared test was used to compare between male/female, public/private clinical placements and public/private colleges, respectively.

Results: Of the participants $79 \%(n=57)$ were male and $21 \%(n=15)$ were female. Mean age of participants was $24.29 \pm 1.72$ years. Four barriers in clinical education due to deficiencies in educational institutions included: shortage of clinical teachers (76.4\%), clinical teachers rarely visited students (75\%), too many students were supervised by a single teacher (81.9\%) and students are overloaded with too many written assignments (75\%). The $P$-value for shortage of clinical teachers was statistically significant $(P=0.016)$. The main barriers in clinical education attributed to clinical settings or the hospitals were behavior of the hospital staff resulting in the loss of students' confidence (73.6\%) and anxiety of students to perform wrong procedures (73.6\%). However, none of these barriers in clinical education were statistically significant $(P>0.05)$.

Conclusions: Findings of the study illustrated dissatisfaction of graduate nursing internees regarding the clinical education as almost all the issues received more than $50 \%$ responses.

Key words: Clinical placement, Clinical Nursing teacher, Nursing internees, Student nurses

\section{Authors' Contribution: \\ 1,2 Conception; Literature research; manuscript design and drafting; Critical \\ Correspondence: \\ Asghar Khan \\ Email:asghar802@gmail.com} analysis and manuscript review; Data analysis; Manuscript Editing.

Article info:

Received: November 29, 2019

Accepted: September 16, 2020
\end{abstract}

Cite this article. Khan $A$, Begum $H$. Issues in Clinical Learning Environment among Undergraduate Nursing Students in Khyber Pakhtunkhwa, Pakistan. J Islamabad Med Dental Coll. 2020; 9(3): 182-189. Doi: 10.35787/jimdc.v9i3.467

Funding Source: Nil

Conflict of Interest: Nil

\section{Introduction}

Undergraduate Nursing education consists of two interrelated elements: theoretical domain and practical training or clinical domain. ${ }^{1,2}$ In clinical education, nursing students acquire, develop and 
gain practical skills and experiences and associate them to theoretical knowledge to resolve the complex problems of patient and to provide safe care with critical thinking. ${ }^{3}$ Clinical placements are the learning environments that comprise of staff nurses, doctors, paramedical staff, constant shift changes, patients' families and patients ${ }^{4}$ with complex medical and nursing needs. ${ }^{5}$ Therefore, clinical learning serves as an integral part of nursing curriculum in order to provide nursing students the opportunities to practice and become competent in the knowledge and skills which are important for professional practices. ${ }^{6}$ Literature has identified a range of hindrances to clinical learning including anxiety of possible criticism from other students, committing mistakes, communication with health care team and patients, approach to critically ill patients, the inappropriate behavior of clinical staff nurses, ${ }^{7}$ ward environment, the culture and complexities of care and the supervisory relationship between students, clinical and educational institutions. ${ }^{8}$

Poor learning environment has adverse effects on the professional development process, and its dynamic nature could pose challenges to the students. ${ }^{1}$ Various studies have reported the failure of clinical settings and even claimed it as a source of stress, resulting in feelings of fear and anxiety, ultimately affecting the students' responses to learning. ${ }^{8}$ Consequently, the poor learning environment negatively affects patients' care. ${ }^{9}$

Thus, there is a need for empirical and contextual evidence of clinical learning issues, in order to provide guidance for reforms in the nursing curricula, policy making for clinical rotations and decision making for clinical placement. The previous literature on the subject revealed both quantitative and qualitative studies but we did not find indigenous study regarding clinical learning based on perceptions of nursing internees. The Nursing internees-based information may be more reliable due to the recent clinical exposure and their ability to recollect past experiences as a student.

Nursing education in Pakistan includes two programs i.e. three years Diploma in Nursing (general nursing) and four years Bachelor of Science in Nursing (BScN). During graduation, student nurses are required to complete specific hours on clinical placements according to the curriculum. During clinical placements, the students are supervised by the college faculty members and the hospital nursing staff. Upon graduation, students need to complete one year of practical training as an internee under supervision of the hospital.

In clinical placements, students confront multiple challenges stemming from clinical settings as well as from educational institutions. This study was designed to identify the barriers or problems encountered by the nursing students in clinical settings during the four-year undergraduate training period leading to graduation. The purpose of the study was to highlight clinical problems of undergraduate student nurses. The results of the study may be used to reorganize clinical practice by Nursing teachers and educational institutions.

\section{Material and Methods}

A descriptive cross-sectional study design was used. Data was collected from the BSCN Internees about their pre-graduation clinical experiences at Nursing Colleges of Khyber Pakhtunkhwa, Pakistan, working under supervision of experienced nurses. This study was conducted from April 2019 to August, 2019. The sample comprised of 72 graduate Nursing Internees selected through census sampling technique. All nursing graduates in their internship, working in KPK were included in the study. Those Nursing Internees who had exceeded longer than one year of duration between the completion of graduation and the beginning of internship were excluded from the study. Ethical consent (PSNC-Eth-03) was taken from the Ethical Committee of Pak-Swiss Nursing College, 
Swat. Data was collected through a pre-tested, selfdesigned, structured questionnaire (Cronbach's alpha=0.81). Written Informed consent was obtained from all the participants. They were fully informed of the purpose of the study and they had the right to refuse. The questionnaire was divided into three parts i.e. demographic data, clinical setting-related issues and college-related issues. It was in the form of Likert scale, having options; strongly agree, agree, disagree and strongly disagree. Likert Scale responses were reduced to dichotomy "strongly/agree and disagree/strongly disagree" into agree and disagree in order to minimize differences in extreme responses and for simplification of analysis. ${ }^{10}$ Agreement of participants' opinion was considered as alarming barrier when $\geq 70 \%$ responded with agreed/strongly agreed. Statistical Package for Social Sciences (SPSS) software version 22 was used for analysis of data. Descriptive statistics were utilized for demographic data including frequencies, and percentages. Chisquared test was used to analyze the relationship of clinical issues and gender as well as organizations. Analyses were performed between independent variable, organization (public and private) and the dependent variable i.e. barriers to clinical learning. A $P$-value of less than 0.05 was considered statistically significant.

\section{Results}

The participants of this study consisted of 72 BSC Nursing internees. The mean age of participants was $24.29 \pm 1.72$ years (age range $22-34$ years). Table II illustrates the barriers in clinical education attributed to deficiencies in clinical settings or the hospitals which the students had attended for their clinical practice. The alarming barriers were behavior of the hospital staff resulting in the loss of students' confidence (73.6\%) and anxiety of students to perform wrong procedures (73.6\%). Almost all of the barriers were equally present in both genders, public/private colleges and in public/private hospitals. A greater proportion of females as compared to males agreed that there was a shortage of patients $(P=0.008)$. Majority of the students from private colleges agreed that fundamental facilities were deficient in the clinical placement $(P=0.043)$, experience on the first day of the clinical placement was not positive for the rest of the duration $(P=0.031)$ and the learning resources were inadequate in the clinical areas $(P=0.003)$.

Table III reveals barriers in clinical education due to deficiencies in educational institutions. Four alarming barriers were reported by the participants: shortage of clinical teachers $(76.4 \%)$, clinical teachers rarely visited students (75\%), too many students were supervised by a single teacher (81.9\%) and students were overloaded with many written assignments (75\%). Most of these barriers existed equally in male/female perceptions, public/private colleges and public/private clinical placements. All the female internees reported the shortage of clinical teachers $(P=0.016)$.

\begin{tabular}{|c|c|c|}
\hline \multicolumn{3}{|c|}{$\begin{array}{l}\text { Table I: Demographic characteristics of the stuc } \\
\text { participants }\end{array}$} \\
\hline \multicolumn{2}{|c|}{ Demographic Variables } & n (\%) \\
\hline \multirow{2}{*}{ Gender } & Male & $57(79)$ \\
\hline & Female & $15(21)$ \\
\hline \multirow{2}{*}{ Clinical Placement } & Public & $31(43)$ \\
\hline & Private & $41(57)$ \\
\hline \multirow{2}{*}{ Nursing Colleges } & Public & $15(21)$ \\
\hline & Private & $57(79)$ \\
\hline \multicolumn{3}{|c|}{ Discussion } \\
\hline
\end{tabular}

Findings of the current study revealed that majority of the students agreed with the existence of barriers in clinical settings through their responses, which gives an overall impression of dissatisfaction. Moreover, only six of the issues were identified to be alarming. These issues may compromise learning environment with a negative impact on patients' care. 


\begin{tabular}{|c|c|c|c|c|c|c|}
\hline \multicolumn{7}{|c|}{$\begin{array}{l}\text { Table-II: Clinical setting barriers and their association with male/female, public/private colleges and public } \\
\text { private hospitals }\end{array}$} \\
\hline \multirow[b]{2}{*}{ S. No } & \multirow[b]{2}{*}{ Clinical Issues } & \multicolumn{2}{|c|}{ Responses } & \multicolumn{3}{|c|}{$\mathrm{X}^{2}$ of demographic } \\
\hline & & $\begin{array}{c}\text { Agree } \\
\mathrm{n}(\%)\end{array}$ & $\begin{array}{c}\text { Disagree } \\
\mathrm{n}(\%)\end{array}$ & 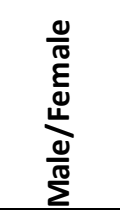 & 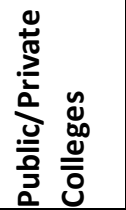 & 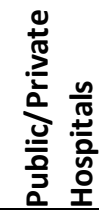 \\
\hline 1 & Adequate equipment was not available & $42(58.3)$ & $30(41.7)$ & 0.883 & 0.106 & 0.658 \\
\hline 2 & $\begin{array}{l}\text { Hospital staff did not provide accurate } \\
\text { information }\end{array}$ & $47(65.3)$ & $25(34.7)$ & 0.089 & 0.899 & 0.703 \\
\hline 3 & $\begin{array}{l}\text { Hospital staff's behavior made you lose your } \\
\text { confidence }\end{array}$ & $53(73.6)$ & $19(26.4)$ & 0.179 & 0.528 & 0.524 \\
\hline 4 & Hospital staff was not cooperative & $44(61.1)$ & $28(38.9)$ & 0.197 & 0.620 & 0.645 \\
\hline 5 & The hospital environment was not clean & $39(54.2)$ & $33(45.8)$ & 0.610 & 0.216 & 0.921 \\
\hline 6 & $\begin{array}{l}\text { Fundamental facilities (drinking water, lift, } \\
\text { wheelchair, and toilets) were not available }\end{array}$ & $31(43.1)$ & $41(56.9)$ & 0.366 & $0.043^{*}$ & 0.202 \\
\hline 7 & $\begin{array}{l}\text { The first day experience was positive for the } \\
\text { rest of the clinical duration }\end{array}$ & $37(51.3)$ & $35(48.6)$ & 0.866 & $0.031^{*}$ & 0.974 \\
\hline 8 & $\begin{array}{l}\text { Preceptor did not regularly supervise us in } \\
\text { actual patient situations }\end{array}$ & $39(54.2)$ & $33(45.8)$ & 0.512 & 0.942 & 0.392 \\
\hline 9 & $\begin{array}{l}\text { The hospital nursing staffs did not supervise } \\
\text { us efficiently }\end{array}$ & $47(65)$ & $25(34.7)$ & 0.275 & 0.899 & 0.703 \\
\hline 10 & $\begin{array}{l}\text { The hospital staff discouraged us to seek } \\
\text { guidance from them in clinical duration. }\end{array}$ & $38(52.7)$ & $34(47.2)$ & 0.594 & 0.594 & 0.435 \\
\hline 11 & The patient's relatives were not cooperative & $38(52.7)$ & $34(47.2)$ & 0.529 & 0.529 & 0.863 \\
\hline 12 & Felt anxiety to perform wrong procedure & $53(73.6)$ & $19(26.3)$ & 0.493 & 0.179 & 0.658 \\
\hline 13 & $\begin{array}{l}\text { Inappropriate behavior by doctors and } \\
\text { nurses with nursing teacher and student }\end{array}$ & $48(66.6)$ & $24(33)$ & 0.538 & 1.00 & 0.064 \\
\hline 14 & $\begin{array}{l}\text { Lack of opportunities to practice or not } \\
\text { allowed taking part in practice according to } \\
\text { objectives }\end{array}$ & $47(65.2)$ & $25(34.7)$ & 0.275 & 0.275 & 0.537 \\
\hline 15 & $\begin{array}{l}\text { The students were assigned inappropriate } \\
\text { and heavy workload by the hospital staff. }\end{array}$ & $47(65.2)$ & $25(34.7)$ & 0.899 & 0.899 & 0.537 \\
\hline 16 & $\begin{array}{l}\text { The learning resources were inadequate in } \\
\text { the clinical areas }\end{array}$ & $43(59.7)$ & $29(40.2)$ & 0.571 & $0.003^{*}$ & 0.088 \\
\hline 17 & $\begin{array}{l}\text { There was shortage of patients in the clinical } \\
\text { areas }\end{array}$ & $19(26.3)$ & $53(73.6)$ & $0.008^{*}$ & 0.493 & 0.524 \\
\hline 18 & $\begin{array}{l}\text { Non supportive environment due to many } \\
\text { patients in the clinical areas }\end{array}$ & $40(55.5)$ & $32(44.4)$ & 0.846 & 0.052 & 0.558 \\
\hline 19 & $\begin{array}{l}\text { Inadequate PPE (personal protective } \\
\text { equipment) exposed to infection in the } \\
\text { clinical areas }\end{array}$ & $42(58.3)$ & $30(41.6)$ & 0.303 & 0.462 & 0.355 \\
\hline 20 & $\begin{array}{l}\text { There was lack of coordination between the } \\
\text { college and hospital }\end{array}$ & 43 (59.7) & $29(40.2)$ & 0.247 & 0.980 & 0.814 \\
\hline 21 & $\begin{array}{l}\text { The clinical placement did not contribute to } \\
\text { increase awareness for my future nursing } \\
\text { role }\end{array}$ & $45(62.5)$ & $27(37.5)$ & 0.410 & 0.330 & 0.424 \\
\hline
\end{tabular}

*Significant with $P$-value of $<0.05$ 


\begin{tabular}{|c|c|c|c|c|c|c|}
\hline \multirow[b]{2}{*}{$\begin{array}{l}\text { S. } \\
\text { No }\end{array}$} & \multirow[b]{2}{*}{ Educational Institutional Issues } & \multicolumn{2}{|c|}{ Responses } & \multicolumn{3}{|c|}{$\mathrm{X}^{2}$ of demographic } \\
\hline & & $\begin{array}{l}\text { Agree } \\
\mathrm{n}(\%)\end{array}$ & $\begin{array}{l}\text { Disagree } \\
\text { n (\%) }\end{array}$ & 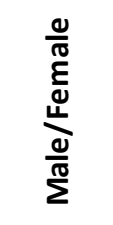 & 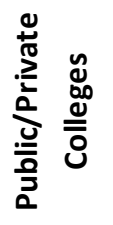 & 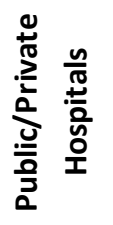 \\
\hline 1 & $\begin{array}{l}\text { Inadequate information from the college to } \\
\text { prepare us well for clinical work }\end{array}$ & $39(54.2)$ & $33(45.8)$ & 0.512 & 0.610 & 0.392 \\
\hline 2 & $\begin{array}{l}\text { Inadequate teaching and skill training in the } \\
\text { college to prepare us for clinical }\end{array}$ & $29(40.3)$ & $43(59.7)$ & 0.538 & 0.980 & 0.471 \\
\hline 3 & $\begin{array}{l}\text { Lack of supervision from the teacher to } \\
\text { contribute to increased learning }\end{array}$ & $39(54.2)$ & $33(45.8)$ & 0.942 & 0.942 & 0.564 \\
\hline 4 & $\begin{array}{l}\text { There was inadequate guidance from the } \\
\text { teachers to take initiative }\end{array}$ & $36(50)$ & $36(50)$ & 0.147 & 0.772 & 0.475 \\
\hline 5 & $\begin{array}{l}\text { Assignments from the college were not } \\
\text { consistent with learning opportunities at the } \\
\text { clinical area }\end{array}$ & $31(43.1)$ & $41(56.9)$ & 0.788 & 0.788 & 0.427 \\
\hline 6 & $\begin{array}{l}\text { There was lack of cooperation from other } \\
\text { students at the clinical area }\end{array}$ & $40(55.6)$ & $32(44.4)$ & 0.330 & 0.436 & 0.709 \\
\hline 7 & The teachers did not evaluate students fairly & $44(61.1)$ & $28(38.9)$ & 0.275 & 0.059 & 0.606 \\
\hline 8 & $\begin{array}{l}\text { Students were anxious about starting clinical } \\
\text { practice }\end{array}$ & $50(69.4)$ & $22(30.6)$ & 0.713 & 0.372 & 0.807 \\
\hline 9 & $\begin{array}{l}\text { The students were afraid of criticism by } \\
\text { clinical teachers }\end{array}$ & $50(69.4)$ & $22(30.6)$ & 0.319 & 0.793 & 0.201 \\
\hline 10 & $\begin{array}{l}\text { There was lack of competency of clinical } \\
\text { teachers. }\end{array}$ & $44(61.1)$ & $28(38.9)$ & 0.092 & 0.620 & 0.316 \\
\hline 11 & $\begin{array}{l}\text { Lack of guidelines for nursing practice or } \\
\text { uneasiness in the working climate }\end{array}$ & $49(68.1)$ & $23(31.9)$ & 0.897 & 0.622 & 0.575 \\
\hline 12 & Clinical teachers were not well prepared & $49(68.1)$ & $23(31.9)$ & 0.622 & 0.082 & 0.645 \\
\hline 13 & $\begin{array}{l}\text { Shortage of clinical teachers or someone to } \\
\text { guide in clinical area }\end{array}$ & $55(76.4)$ & $17(23.6)$ & $0.016^{*}$ & 0.711 & 0.858 \\
\hline 14 & $\begin{array}{l}\text { Clinical teachers rarely visited students in the } \\
\text { clinical areas }\end{array}$ & $54(75)$ & $18(25)$ & 0.065 & 0.615 & 0.216 \\
\hline 15 & $\begin{array}{l}\text { Too many students were supervised by a } \\
\text { single teacher }\end{array}$ & $59(81.9)$ & $13(18.1)$ & 0.197 & 0.826 & 0.108 \\
\hline 16 & $\begin{array}{l}\text { Students were overloaded with too much } \\
\text { written assignments by the clinical teacher }\end{array}$ & $54(75)$ & $18(25)$ & 0.615 & 0.132 & 0.216 \\
\hline
\end{tabular}

* Significant with $P$-value of $<0.05$

Thus, the confidence and competence of nursing students will be reduced which is crucial for their professional development. The Chi square test results show that majority of problems exist equally in all groups i.e. male/female, public/private hospitals and public/private colleges. The institutional based problems included shortage of clinical teachers, rare interaction of clinical teachers with students, too many students being supervised by a single teacher and the students being overburdened with too many written assignments. All the female internees reported the shortage of clinical teachers $(P=0.016)$. The clinical settings or the hospital-based problems included behavior of the hospital staff resulting in the loss of students' 
confidence and anxiety of students to perform wrong procedures.

Hart and Rotem have defined the clinical learning environment as the attributes of the clinical work setting, which the nursing staff perceives to improve their professional development. ${ }^{7}$ Researchers have discussed the dynamic nature of the clinical environment. They argue that students learning in the clinical environment is unpredictable and far beyond the control of faculty members. ${ }^{8}$ Therefore, a close collaboration is expected between the clinical staff and clinical teachers for the accomplishment of clinical practice, students' satisfaction and competence. This fact has been highlighted by majority of students in the current study as they reported that the behavior of the hospital staff resulted in the loss of their confidence. The students provide care to the patients but they are not independent. These students need emotional support from the clinical staff as reported by Chin from a previous study that students are concerned about the reaction of the health care staff to their efforts. ${ }^{7,11}$ Literature illustrates that collaboration between clinical placement and educational institutes enhance nursing education, thereby ensuring accomplishment of learning outcomes. ${ }^{12}$

The anxiety level of students increases when they are sent to clinical placements to work with real patients after gaining theoretical knowledge. ${ }^{9}$ In the current study, $73.6 \%$ of the respondents reported that they felt anxiety out of fear that they would perform wrong procedures. The clinical environment may cause anxiety in students due to the working process, the healthcare environment, the healthcare staff, fear of making errors, ${ }^{13}$ and being evaluated by clinical teacher. ${ }^{14}$ In order to reduce their anxiety level, it is important for them to practice adequately in skill laboratory. Low level of anxiety improves learning by improving selfconfidence. Various studies have illustrated the factor of anxiety in the clinical setting of the nursing students. ${ }^{8,11,14,15}$ The factor of anxiety may also be minimized by increased collaboration between nursing institution and the staff of clinical placement and by the presence of a clinical teacher in the hospital.

The shortage of qualified nurses in Pakistan has challenged educational institutions to hire and retain the best qualified faculty staff. This shortage of clinical faculty affects the clinical learning environment directly. Students in the current study have reported the shortage of clinical teachers as an alarming issue in nursing education. Phillips et al. have also highlighted the shortage of clinical faculty. ${ }^{6}$ Furthermore, they have identified the reasons for faculty shortage including lower compensation of faculty nurses compared to clinical nurses, less attractive position of faculty members, aging nursing faculty, and lack of facilities for nurses to obtain higher education. ${ }^{6}$ Students in the current study have also reported that clinical teachers rarely visit them in clinical placement and too many students are supervised by a single clinical teacher as an alarming barrier. A study conducted in China demonstrated uncertainty among students in relation to what they could expect from the clinical teachers. ${ }^{16}$ In contrast to these findings, some studies have demonstrated positive perceptions of students regarding their clinical teacher. ${ }^{17}$ Few studies support the perceptions of these students and suggest that the number of students under a clinical teacher must be low. ${ }^{7}$ It is the responsibility of clinical teacher to identify students' needs and work with clinical staff to foster a best possible environment conducive to undergraduate nursing students' learning. ${ }^{15,18}$ Some of the studies which reported the positive perceptions regarding clinical teachers have been conducted in countries where nursing is a developed profession. Additionally, there is lesser shortage of qualified nurses and the work burden is low. The poor situation in clinical learning environment in relation to faculty can be 
improved by facilitating higher education. Consequently, the shortage of clinical faculty may be minimized. Clinical teachers rarely visit their students on clinical placement due to huge burden on them. ${ }^{19}$ This issue can be minimized by hiring an increased number of faculty in the educational institutions.

Extensive research is needed especially interventional, ${ }^{20}$ in order to produce deeper understanding of the inherent issues in the clinical learning environment. This would help in transforming the current situation to improve the level of satisfaction and thus produce skilled, qualified and professional nurses.

Limitation: During this study, the major limitations was a small sample because of a small target population, thus limiting generalizability of the study findings. Moreover, census sampling technique was used instead of the probability sampling clinical learning environment, as the latter technique would have been more useful if we had a larger population of nursing interns.

\section{Conclusion}

The current study concluded that nursing internees were not satisfied with the clinical learning environment comprising of issues related to clinical placements and nursing educational institutions. A concerted effort is required by the educators to modify nursing curriculum, improve collaboration with the management and nursing staff of the hospital and reduce the shortage of clinical faculty in the nursing institutions. Otherwise, the chances of producing highly skilled, knowledgeable and professional nurses may be reduced.

\section{Acknowledgment}

The authors express their gratitude to all the participants of this study, and to Mr. Ayaz Khan, Nursing Manager of Northwest General Hospital and
Research Center, for his utmost cooperation in the collection of data.

\section{References}

1. Jamshidi N, Molazem Z, Sharif F, Torabizadeh C, Kalyani MN. The challenges of nursing students in the clinical learning environment: A Qualitative Study. Sci World J. 2016; ID: 1846178. Doi: 10.1155/2016/ 1846178

2. Gemuhay HM, Kalolo A, Mirisho R, Chipwaza B, Nyangena E. Factors affecting performance in clinical practice among preservice diploma nursing students in Northern Tanzania. Nurs Res Pract. 2019; ID: 3453085. Doi: 10.1155/2019/3453085

3. Farzi S, Shahriari M, Farzi S. Exploring the challenges of clinical education in nursing and strategies to improve it: A qualitative study. J Educ Health Promot. 2018; 7: 115. Doi: 10.4103/jehp.jehp_169_17

4. Mohamed N, Mokadem EL, Ibraheem SE. Nursing students' satisfaction with their clinical learning environments. Am J Nurs Res. 2017;5(4):104-8. Doi: 10.12691/ajnr-5-4-1

5. Stenberg M, Carlson E. Swedish student nurses' perception of peer learning as an educational model during clinical practice in a hospital setting - an evaluation study. BMC Nurs. 2015; 14(1): 48. Doi: 10.1186/s12912-015-0098-2

6. Phillips KF, Mathew L, Aktan N, Catano B. Clinical education and student satisfaction: An integrative literature review. Int J Nurs Sci. 2017;4(2):205-13. Doi:10.1016/j.ijnss.2017.03.004

7. Kapucu S, Bulut H. Turkish nursing students' views of their clinical learning environment: A focus group study. Pak J Med Sci. 2011;27(5):1149-53.

8. Papastavrou E, Lambrinou E, Tsangari H, Saarikoski M, Leino-Kilpi H. Student nurses experience of learning in the clinical environment. Nurse Educ Pract. 2010; 10(3): 176-Doi:10.1016/j.nepr.2009.07.003

9. Makhlof EHA, El-saman SEA. Internship nurses' satisfaction with clinical learning environment in intensive care unit. IOSR-JNHS. 2017; 6(2): 112-9. Doi:10.9790/1959-060205112119

10. Machaczek K, Whietfield M, Kilner K, Allmark P. Doctors' and Nurses' Perceptions of Barriers to Conducting Handover in Hospitals in the Czech Republic. Am J Nurs Res. 2013; 1(1):1-9 
11. Chan D. Development of the clinical learning environment inventory: Using the theoretical framework of learning environment studies to assess nursing students' perceptions of the hospital as a learning environment. J Nurs Educ. 2002;41(2):6975. Doi: 10.3928/0148-4834-20020201-06

12. Phuma-ngaiyaye $E$, Bvumbwe $T$, Chn M, Chipeta MC. Using preceptors to improve nursing students' clinical learning outcomes: A Malawian students' perspective. Int J Nurs Sci. 2017; 4(2): 164-8. Doi:10.1016/j.ijnss.2017.03.001

13. Pajnkihar $M$, Fekonja Z. Self-reflection during first clinical practice : The experiences of nursing students. Nurse Educ Today. 2019; 72(2018): 61-6. Doi: 10.1016/j.nedt.2018.10.019

14. Sharif F, Masoumi S. A qualitative study of nursing student experiences of clinical practice. BMC Nursing 2005; 4(1):7. Doi: 10.1186/1472-6955-4-6

15. Ahmad N, Hamidah N, Anwar K. Nursing students and clinical instructors' perceptions of clinical learning environments, supervision, and teaching (CLES-T). IJCS. $2018 ; 1(1)$ : 10-3.

16. Liu ZX, Liu XS, Liu H, Song YL. Nursing undergraduates' satisfaction of the clinical learning environment in
China. International Conference on Information, Computer and Education Engineering (ICICEE). 2017;

143-149. Doi: 10.12783/dtcse\%2Ficicee $2017 \%$ 2F17136

17. Meyer G, Nel E, Downing C. Basic student nurse perceptions about clinical instructor caring. Heal SA Gesondheid. 2016; 21(1): 444-52. Doi: 10.4102/hsag .v21i0.1007

18. Moscaritolo LM. Interventional Strategies to decrease nursing student anxiety in the clinical learning environment. J Nurs Educ. 2009; 48(1): 1724. Doi: 10.3928/01484834-20090101-08

19. Khan A, Begum $H$, Rehman AU, Khan A. Experiences of Healthcare Students and the Challenges Posed by Their Clinical Learning Environment. CEJNM. 2020;11(1): 19-24. Doi:10.15452/CEJNM.2020.11. 0004

20. Kurian RN, James MM. Assessment of level of satisfaction of student nurses with their clinical learning environment in a selected college of nursing in New Delhi, India. Int J Curr Res. 2017; 9(12): 6258992 